\title{
Extraction of Cecropia Pachystachya Leaves by Supercritical Carbon Dioxide: Kinetics, Phytochemical Characterization, Antibacterial and Antioxidant
}

\author{
Activities \\ Jaqueline Hoscheid (Corresponding author) \\ Programa de Mestrado Profissional em Plantas Medicinais e Fitoterápicos na Atenção \\ Básica, Universidade Paranaense, Umuarama, PR, Brazil. \\ E-mail: jaqueline.hoscheid@gmail.com
}

\begin{abstract}
Joice Karina Otenio
Programa de Mestrado Profissional em Plantas Medicinais e Fitoterápicos na Atenção Básica, Universidade Paranaense, Umuarama, PR, Brazil.

E-mail: joice_otenio@hotmail.com
\end{abstract}

Emerson Luiz Botelho Lourenço

Programa de Pós-graduação em Ciência Animal com ênfase em Produtos Bioativos, Universidade Paranaense, Umuarama, PR, Brazil.

E-mail: emerson@prof.unipar.br

\begin{abstract}
Elissandro Jair Klein
Programa de Pós-graduação em Engenharia Química, Faculdade de Engenharia Química, Universidade Estadual de Campinas, Campinas, SP, Brazil.

E-mail: elissandro.klein@hotmail.com
\end{abstract}

Camila da Silva

Programa de Pós-graduação em Engenharia Química, Universidade Estadual de Maringá (UEM), Maringá, Paraná, Brazil. 
E-mail: camiladasilva.eq@gmail.com

\title{
Guilherme Donadel
}

Programa de Pós-graduação em Ciência Animal com ênfase em Produtos Bioativos, Universidade Paranaense, Umuarama, PR, Brazil.

E-mail: g.donadel@edu.unipar.br

\section{Kátia Andressa Santos}

Centro de Engenharias e Ciências Exatas, Universidade Estadual do Oeste do Paraná, Toledo, PR, Brazil.

E-mail: katiandressa@hotmail.com

\section{Edson Antônio da Silva}

Centro de Engenharias e Ciências Exatas, Universidade Estadual do Oeste do Paraná, Toledo, PR, Brazil.

E-mail: edsondeq@ hotmail.com

Received: Sep. 23, 2020

doi:10.5296/jas.v8i4.17723
Accepted: Oct. 18, $2020 \quad$ Published: Oct. 19, 2020

URL: https://doi.org/10.5296/jas.v8i4.17723

\begin{abstract}
Cecropia pachystachya Trécul is popularly known in Brazil as embaúva or embaúba. Pharmacological activities were reported in extant studies including the development of anxiolytic, antidepressant, hypoglycemic, antioxidant, cardiotonic, sedative, anti-inflammatory, antimicrobial and leishmanicidal properties for aqueous and alcoholic extracts prepared by infusion or maceration of $C$. pachystachya leaves. However, there is a paucity of studies examining extracts of leaves of $C$. pachystachya obtained by supercritical fluid technology. This study evaluated the extraction of Cecropia pachystachya oil using supercritical carbon dioxide $\left(\mathrm{CO}_{2}\right)$. Extractions were performed at $35{ }^{\circ} \mathrm{C}, 45{ }^{\circ} \mathrm{C}$, and $55{ }^{\circ} \mathrm{C}$ and $14 \mathrm{MPa}, 17 \mathrm{MPa}$, and $20 \mathrm{MPa}$. The extraction yield, characteristics of the oil, antioxidant and antibacterial potentials were evaluated. The highest extraction yield obtained from $C$. pachystachya leaves was $1.48 \%$ using supercritical $\mathrm{CO}_{2}$ at $55{ }^{\circ} \mathrm{C}$ and $20 \mathrm{MPa}$. The main identified compounds include terpenoids (ursolic and pomolic acids, squalene and $\beta$-sitosterol). The most promising results for antibacterial activity relative to Staphylococcus
\end{abstract}


aureus and antioxidant potentials were observed on the extract obtained at $55^{\circ} \mathrm{C}$ and $14 \mathrm{MPa}$. The mathematical Sovová model satisfactorily represented the experimental data.

Keywords: embaúba, Sovová model, supercritical extraction, antimicrobial activity, antioxidant potential

\section{Introduction}

Cecropia pachystachya Trécul (Urticaceae) is popularly known in Brazil as embaúva, embaúba, or tore and is a tree that is used for ornamental and medicinal purposes. In Brazil is widely used in traditional medicine for treating respiratory infections (Da Silva et al., 2010), hyperlipidemia (Souza \& Felfili, 2006), and diabetes (Rodrigues \& Carvalho, 2001). It is also used as a diuretic (Rocha et al. 2007). Pharmacological activities were reported in extant studies including the development of anxiolytic, antidepressant (Velázquez et al., 2003; Consolini et al., 2006; Gazal et al., 2014; Ortmann et al., 2016), hypoglycemic (Aragão et al., 2010), antioxidant (Consolini et al., 2006; Farias et al., 2013; Souza et al., 2014; Pacheco et al., 2014), cardiotonic (Consolini \& Migliori, 2005; Gazal et al., 2014), sedative (Hikawczuk et al., 1998), anti-inflammatory (Pacheco et al., 2014; Maquiaveli et al., 2014), antimicrobial (Souza et al., 2014), and leishmanicidal (Cruz et al., 2013) properties for aqueous and alcoholic extracts prepared by infusion or maceration of $C$. pachystachya leaves.

Phytochemical surveys already indicated the presence of several groups of flavonoids, tannins (Souza et al., 2014; Ortmann et al., 2016; Ortmann et al., 2017), and catechins (Costa et al., 2011; Cruz et al., 2013). High-performance liquid chromatographic analyses allowed the identification of the flavonoids C-glycosides including isoorientin, isovitexin, orientin, vitexin, and rutin (Costa et al., 2011; Brango-Vanegas et al., 2014), and chlorogenic acid (Brango-Vanegas et al., 2014).

The quality of the vegetal extracts is extremely influenced by the methodology of extraction employed. However, non-optimized processes limit the extractive potential and consequently interfere in the pharmacological activity. Extracts rich in phenolic compounds including flavonoids and tannins are obtained by various solvent extraction techniques and more recently by supercritical fluid technology (Souza-Moreira et al., 2010).

Extraction using supercritical $\mathrm{CO}_{2}$ fluid technology is attractive due to selectivity, solubility, and mass transfer rates. The selectivity of the extraction process mainly depends on the density of the supercritical $\mathrm{CO}_{2}$, and this can be altered by varying the process conditions (Subroto et al., 2017). The low latent heat of evaporation in the process and the high volatility of the solvents make it possible to obtain extracts free of toxic residues and to preserve thermally degradable products, thereby obtaining extracts with high quality when compared to the products obtained by conventional techniques (Souza-Moreira et al., 2010; Martinez-Correa et al., 2017). Furthermore, this technique is considered green technology because the solvent is completely removed after the extraction process (Martinez-Correa et al., 2017). However, there is a paucity of studies examining extracts of leaves of $C$. pachystachya obtained by supercritical fluid technology. The objective of the present study is to evaluate the kinetics of supercritical $\mathrm{CO}_{2}$ extraction, effects of temperature and pressure on 
yield and antimicrobial and antioxidant activities, and to perform a preliminary chemical characterization of the compounds present in the extracts.

\section{Method}

\subsection{Plant Material Preparation and Characterization}

The plant material was collected at Quatro Pontes, Paraná state, Brazil (24³5'40.56”'S; $53^{\circ} 57^{\prime} 46.60^{\prime \prime} \mathrm{W}$ ). The species were identified and a voucher (no. 3000) was deposited at the Herbarium of the West Paraná State University. The material was dried in an oven at $40{ }^{\circ} \mathrm{C}$ for 3 days and was ground by a knife grinder. The average size of the particles $(720 \mu \mathrm{m})$ of $C$. pachystachya leaves was determined by using a Master-Sizer particle analyzer (Malvern Instrument Ltda). The moisture content of the leaves $(2.94 \pm 0.03 \mathrm{wt} \%)$ was obtained by using the gravimetric method to dry sample at $105^{\circ} \mathrm{C}$ until the mass stabilized. The density $\left(1.44 \mathrm{~g} \cdot \mathrm{cm}^{-3}\right)$ of the investigated sample was determined by pycnometer by using helium gas (Micromeritics, AccuPyc model 1330) (Santos et al., 2015).

\subsection{Chemicals}

Carbon dioxide > 99\% (Linde) was used in the supercritical extractions. For the total phenolic concentrations, Folin \& Ciocalteu's phenol reagent and gallic acid from Sigma Aldrich were used. Mueller-Hinton agar (Merck) was used in the microbiological analyses. DPPH (2,2-diphenyl- 1-picrylhydrazyl), ABTS (2,2_-azino-bis(3-ethylbenzothiazoline6-sulfonic acid)), TPTZ (2,4,6-tris(2-pyridyl)-s-triazine), Trolox (6-hydroxy-2,5,7,8-tetramethylchromane-2-carboxylic acid), all from Sigma Aldrich, were used for antioxidant analysis.

\subsection{Cecropia pachystachya Oil Extractions}

The extractions were performed in a laboratory-scale unit. The equipment consists of a stainless steel extractor with a capacity of $58 \mathrm{~cm}^{3}$ (with a height of $19.4 \mathrm{~cm}$ and a diameter of $1.95 \mathrm{~cm}$ ), a solvent reservoir, a Syringe pump (Isco, 500D model), and two thermostatic baths. The extractions were performed with pure carbon dioxide $\left(\mathrm{CO}_{2}\right)$.

A full factorial experimental $2^{2}$ design with center points was used to analyze the influence of the independent variables pressure, and temperature, on the extraction yield. The experiments were performed at pressures of $14 \mathrm{MPa}, 17 \mathrm{MPa}$, and $20 \mathrm{MPa}$ and temperatures of $35^{\circ} \mathrm{C}, 45$ ${ }^{\circ} \mathrm{C}$, and $55^{\circ} \mathrm{C}$. The selection of pressure and temperature conditions allowed an increase in the solvating capacity of the solvent and was based on the equipment limits (Santos et al., 2016).

In each extraction, the vessel was completely loaded with the material. After pressurization, contact between the solvent and material was maintained for 30 minutes, and then the micrometric valve was opened for a solvent mass flow rate of $1.96 \mathrm{~g} \mathrm{~min}^{-1}$. The oil was collected in an amber vessel, and its mass $(\%, w / w)$ was determined at time intervals of 10 min (up to $150 \mathrm{~min}$ of extraction). The yields were calculated as the ratio of the extracted oil mass to the initial $C$. pachystachya leaves mass. The experimental data were statistically analyzed using Statistica ${ }^{\mathrm{TM}}$, version 7.0 software (Statsoft) at the $95 \%$ confidence level. 


\subsection{Kinetics of the C. pachystachya Oil Extraction}

The kinetic curves were described by a second-order model proposed by Sovová (StatSoft, 2007). The model considers two mass transfer mechanisms and three different extraction stages. In the first stage, the extraction of directly exposed oil (bioactive compounds) in the fluid phase occurs. This step depends on the solubility in the fluid phase and is characterized by a linear curve with a slope close to the solubility value of the oil in the solvent (Silva et al., 2015). Subsequently, a decrease in the extraction rate occurs at which the fraction of oil on the surface of the cells shows indications of being exhausted. Additionally, the extraction of a low amount of accessible oil occurs, and this is controlled by an internal diffusion mechanism (diffusion mass transfer mechanisms in conjunction with the convection). In the third stage, the extraction curve becomes almost linear at an extraction rate that is significantly lower than that in the first period (Nelder \& Mead, 1965; Liu et al., 2013; Silva et al., 2015; Lopes et al., 2020). The solubility was calculated from the slope of the linear part of the general extraction curves. The parameters $r, Z$, and $W$, were adjusted as previously reported (Santos et al., 2016).

\subsection{Phytochemical Characterization}

\subsubsection{GC-MS Analysis}

Chemical identification was performed on GC-MS QP2010 SE (Shimadzu). Specifically, 10 $\mu \mathrm{L}$ of the samples were diluted with $990 \mu \mathrm{L}$ of dichloromethane (Anidrol) before injecting the same into a SH-RTx-5MS column (Shimadzu, 5\% phenyl-methylsiloxane, $30 \mathrm{~m} \times 0.25 \mathrm{~mm}$ id, $0.25 \mu \mathrm{m}$ ) by using an auto-sampler (Shimadzu AOC-20i). Helium was used as the carrier gas at a flow rate of $1.0 \mathrm{ml} \mathrm{min}{ }^{-1}$ with a split ratio of $2: 1$, and the volume of the injected sample was $1 \mu \mathrm{L}$. The column temperature was initially programmed at $40{ }^{\circ} \mathrm{C}$ and heated at $6{ }^{\circ} \mathrm{C} \mathrm{min}{ }^{-1}$ to reach the final temperature of $300{ }^{\circ} \mathrm{C}$. It remained at this temperature for $10 \mathrm{~min}$. The total time of GC-MS analysis was $53.3 \mathrm{~min}$. The injector and the GC-MS interface temperatures were maintained at $250^{\circ} \mathrm{C}$. Mass spectra were recorded at $70 \mathrm{eV}$ with a mass range from $\mathrm{m} / \mathrm{z} 35$ to $550 \mathrm{amu}$.

\subsubsection{Total Phenolic Content (TPC)}

The TPC of the oils was determined by using the Folin-Ciocalteu methods described previously (Singlenton \& Rossi, 1965). The standard calibration (between 500 and $15.625 \mu \mathrm{g}$ $\mathrm{mL}^{-1}$ ) curve was plotted by using gallic acid given the following equation for the line $\mathrm{y}=$ $0.0064 x+0.1135$ with a correlation coefficient of $R^{2}=0.9932$. All determinations were performed thrice, and the total phenolic content was expressed as $\mu \mathrm{g}$ gallic acid equivalent $/ \mathrm{g}$ of oil $\left(\mu \mathrm{g}_{\mathrm{GAE}} \mathrm{g}_{\mathrm{oil}}{ }^{-1}\right)$.

\subsection{Antioxidant Activity}

\subsubsection{DPPH Radical Assay}

The DPPH method is based on the quantification of the oil, or extract, concentrations necessary to reduce the initial concentration of the radical DPPH by $50 \%$ by the hydrogen and electron donation (Miguel, 2010). The radical scavenging capacities of each oil in 
different concentrations (100-1000 $\mu \mathrm{g} \mathrm{mL}^{-1}$ in ethanol) were estimated according to the method of Choi et al. (2002). Negative control was prepared by mixing $1 \mathrm{~mL}$ of DPPH 0.3 $\mathrm{mM}$ with $2.5 \mathrm{~mL}$ of ethanol. The mixtures were shaken vigorously for $1 \mathrm{~min}$ and left to stand at room temperature $\left(37^{\circ} \mathrm{C}\right)$ in the dark for $30 \mathrm{~min}$. Thereafter, the absorbance for the sample was measured at $517 \mathrm{~nm}$. Essential oils and plant extracts are considered to have antioxidant activity when their $\mathrm{IC}_{50}$ value is less than $250 \mu \mathrm{g} \mathrm{mL}^{-1}$ (Czaikoski et al., 2015).

\subsubsection{FRAP_-Ferric Reducing Antioxidant Analysis}

The FRAP analysis was performed using the methodology of Santos et al. (2016) at $595 \mathrm{~nm}$ using the FRAP reagent as a blank. A standard calibration (100-2000 $\mu \mathrm{M})$ curve was plotted by using ferrous sulfate. All determinations were performed in triplicate, and the antioxidant capacity was expressed as $\mu \mathrm{mol}$ of $\mathrm{Fe}^{2+}$ per $\mathrm{g}$ of oil.

\subsection{3 $\mathrm{ABTS}^{\bullet+}$ Free Radical Scavenging Assay}

The ABTS activity was carried out based on a method developed by Santos et al. (2016). The antioxidant activity of the samples was calculated through the range of the dose-response curve of Trolox reagent $(100-2000 \mu \mathrm{M})$ and presented as $\mu$ mol of Trolox per $\mathrm{g}$ of oil. All reactions were carried out in triplicate.

\subsection{Antibacterial Activity}

Standardized bacterial strains of Staphylococcus aureus (ATCC 25922), Escherichia coli (ATCC 25923), and Pseudomonas aeruginosa (ATCC 27853) were transferred to sterile $0.9 \%$ sodium chloride until a transmittance of $25 \%$ was obtained at a wavelength of $580 \mathrm{~nm}$ by using a colorimeter. An inoculum with $1.0 \%$ in agar was prepared from this suspension by adding $1 \mathrm{~mL}$ of suspension into $100 \mathrm{~mL}$ of sterile Muller-Hinton agar at $46-48{ }^{\circ} \mathrm{C}$ (USP, 2011).

The antibacterial activity was assessed by an agar well diffusion method (CLSI, 2009). This consists of the preparation of plates containing one layer $(20 \mathrm{~mL})$ of sterile solid medium and another layer $(5 \mathrm{~mL})$ of culture medium that is previously inoculated with sensitive microorganisms. After solidification, five holes were created on the culture medium with a sterile perforator in which two of the holes are impregnated with the $C$. pachystachya oils extracted at a concentration of $30 \mathrm{mg} \mathrm{mL}^{-1}$, and two of the holes are impregnated with antibiotics Amoxicillin and Neomycin Sulfate at a concentration of $10 \mathrm{mg} \mathrm{mL}^{-1}$. The fifth hole was used a negative control (sterile $0.9 \%$ sodium chloride). The plates were incubated in a bacteriological oven at $35 \pm 2{ }^{\circ} \mathrm{C}$ for $24 \mathrm{~h}$ (USP, 2011), and the plates were read with a caliper (ANVISA, 2010). All tests were performed thrice.

\subsection{Statistical Analysis}

The significant differences between means of the experimental results were submitted to variance analysis (ANOVA) and compared by performing Tukey's test $(p<0.05)$ by using Statistica 7.0 software (Statsoft, USA). 


\section{Results and Discussion}

\subsection{Extraction Yield}

The experimental conditions used for the oil extraction of $C$. pachystachya leaves, $\mathrm{CO}_{2}$ density, oil solubility $(S)$, and yield obtained for each condition are shown in Table 1 . The $Y s$ values were calculated from the linear part of the extraction curves of the C. pachystachya leaves.

Table 1. Experimental conditions and results for the oil extraction yields of C. pachystachya leaves by using supercritical $\mathrm{CO}_{2}$

\begin{tabular}{ccccccc}
\hline Tests & $\begin{array}{c}\mathrm{T} \\
\left({ }^{\circ} \mathrm{C}\right)\end{array}$ & $\begin{array}{c}\mathrm{P} \\
(\mathrm{MPa})\end{array}$ & $\begin{array}{c}\text { Solvent density } \\
\left(\mathrm{g} \mathrm{cm}^{-3}\right)\end{array}$ & $\begin{array}{c}S^{\mathrm{b}} 10^{-3} \\
\left(\mathrm{~g} \mathrm{~cm}^{-3}\right)\end{array}$ & Time (min) & Yield (wt\%) \\
\hline $\mathrm{A}$ & 35 & 14 & 0.801 & 0.60 & 150 & 0.95 \\
$\mathrm{~B}$ & 35 & 20 & 0.865 & 1.13 & 150 & 1.35 \\
$\mathrm{C}$ & 55 & 14 & 0.618 & 0.60 & 150 & 0.65 \\
$\mathrm{D}$ & 55 & 20 & 0.754 & 1.40 & 150 & 1.48 \\
$\mathrm{E}$ & 45 & 17 & 0.775 & 0.94 & 150 & $1.26 \pm 0.004^{\mathrm{c}}$ \\
\hline
\end{tabular}

Note. ${ }^{\mathrm{a}} \mathrm{CO}_{2}$ density calculated according to NIST (2015). ${ }^{\mathrm{b}}$ Oil solubility in the solvent. ${ }^{\mathrm{c}}$ Average value \pm standard deviation $(n=3)$

Concerning the temperature and pressure conditions investigated in the experimental design, the pressure was the only variable that exhibited a significant effect $(P<0.05)$. It obtained a maximum increase of approximately $127 \%(0.65-1.48 \mathrm{wt} \%)$ for the yield with an increase in the extraction pressure from $14 \mathrm{MPa}$ to $20 \mathrm{MPa}$ at $55^{\circ} \mathrm{C}$. This was observed in previous studies (Ribas et al., 2014; Santos et al., 2016; Santos et al., 2017). Thus, an increase in pressure leads to increases in the solvating power of $\mathrm{CO}_{2}$ and results in a higher extraction yield (Palvic et al., 2017). The temperature did not exhibit a statistically significant influence on the extraction yield at the highest pressure that was used. However, the results suggest a positive effect on this variable. At low pressure (14 MPa), an increase in temperature decreases the yield $\left(0.95\right.$ at $35^{\circ} \mathrm{C}$ and 0.65 at $55^{\circ} \mathrm{C}$, almost $30 \%$ of decrease). Whereas at higher pressure $(20 \mathrm{MPa})$, an increase in temperature slightly increases the yields $\left(1.35\right.$ at $35^{\circ} \mathrm{C}$ and 1.48 at $55^{\circ} \mathrm{C}$ ). Given the opposing effects of vapor pressure and solvent density and on solubility, the effect of temperature is a complicated parameter. This phenomenon is due to the retrograde solubility usually encountered with supercritical $\mathrm{CO}_{2}$, which is due to opposite effects of $\mathrm{CO}_{2}$ density and solute vapor pressure, where the temperature increases with decreases in the solvent density and on solubility (Hatami et al., 2014). A similar effect was reported for the extraction of Lupinus albescens Hook. \& Arn. roots (Conforti et al., 2017), Humulus lupulus L. 
hops (Kupski et al., 2017), and Salvia officinalis L. (Palvic et al., 2017).

The chemical compounds were identified in the oil of $C$. pachystachya extracted with $\mathrm{CO}_{2}$ (Appendix). The samples presented qualitative similarities in their compositions although the changes in temperature and pressure altered the percentage of the components (Table 2).

Table 2. Chemical composition of the oil extracted from $C$. pachystachya leaves by using supercritical $\mathrm{CO}_{2}$
Relative area $(\%)$
Tests

\begin{tabular}{cccccc} 
& $\mathrm{A}$ & $\mathrm{B}$ & $\mathrm{C}$ & $\mathrm{D}$ & $\mathrm{E}$ \\
\hline Ursolic acid & 30.35 & 46.83 & 30.68 & 39.43 & 39.46 \\
Squalene & 15.76 & 13.29 & 18.49 & 16.00 & 12.92 \\
Pomolic acid & 12.76 & 6.88 & 15.39 & 14.53 & 7.79 \\
$\begin{array}{c}\text { B-sitosterol } \\
\text { Vitamin E }\end{array}$ & 3.71 & 6.25 & 6.12 & 0.31 & 8.13 \\
a-amyrin & 2.16 & 1.69 & 1.81 & 2.14 & 4.61 \\
Catechin & 4.49 & 0.91 & 1.49 & 5.29 & 2.40 \\
Isovitexin & 0.29 & 0.14 & 0.34 & 0.19 & 0.14 \\
Isoorientin & 0.25 & 0.34 & 0.35 & 0.31 & 0.43 \\
Chlorogenic acid & 6.58 & 10.9 & 4.00 & 5.97 & 9.55 \\
Others & 17.81 & 9.09 & 14.43 & 11.62 & 12.31 \\
\hline
\end{tabular}

Note. A: $35^{\circ} \mathrm{C} x 14 \mathrm{MPa}, \mathrm{B}: 35^{\circ} \mathrm{C} x 20 \mathrm{MPa}, \mathrm{C}: 55^{\circ} \mathrm{C} x 14 \mathrm{MPa}, \mathrm{D}: 55^{\circ} \mathrm{C} \times 20 \mathrm{MPa}, \mathrm{E}: 45$ ${ }^{\circ} \mathrm{C} x 17 \mathrm{MPa}$

It can be mentioned that approximately 20,000 triterpenes have already been isolated and identified from several medicinal plants, with the tetracyclic and pentacyclic compounds being the most extensively investigated about their pharmacological activities (Yang et al., 2020). Among the triterpenes, squalene it is the simplest representative, being acyclic (Shanmugam et al., 2012). The terpenes $\beta$-sitosterol (Rivera-Mondragón et al., 2017), ursolic and pomolic acids, and $\alpha$-amyrin (Hikawczuk et al., 1998; Rivera-Mondragón et al., 2017), previously found in extracts of $C$. pachystachya leaves, have been identified in a significant 
concentration in our oils. The high concentration of these compounds can be justified by their non-polar characteristics, similar to supercritical $\mathrm{CO}_{2}$ that is a non-polar solvent.

The aqueous and alcoholic extracts obtained from C. pachystachya are widely known for their high composition of flavonoids that include catechin (Costa et al., 2011; Cruz et al., 2013), isoorientin and isovitexin (Costa et al., 2011; Cruz et al., 2013; Brago-Vanegas et al., 2014). Additionally, quantification of the major phenolic compounds in the leaves of $C$. pachystachya showed that chlorogenic acid is the major compound in the aqueous extract of this species (Brago-Vanegas et al., 2014). Despite high content of flavonoids in $C$. pachystachya, the content in oils indicates that only a small part of flavonoids was extracted and much larger part remained in residuum. So the polarity of this solvent does not favor the extraction of flavonoids.

\subsection{Kinetics and Mathematic Modeling of the Extraction}

The apparent $\left(0.775 \mathrm{~g} \mathrm{~cm}^{-3}\right)$ and real $\left(1.447 \mathrm{~g} \mathrm{~cm}^{-3}\right)$ density values obtained allowed the determination of the porosity of the bed (0.812). The characteristics necessary for the implementation of the mathematical Sovová model were as follows: Initial concentration of oil in the inert solid $=0.015 \mathrm{~g} \mathrm{~g}^{-1}$; Bed density $=0.238 \mathrm{~g} \mathrm{~cm}^{-3}$, and solid mass in an oil free base $=11.528 \mathrm{~g}$. The experimental conditions, solubility, and adjustable parameters are shown in Table 3.

Table 3. Adjustable parameters for the Sovová model

\begin{tabular}{cccccccccc}
\hline Tests & $Z$ & $W 10^{-1}$ & $\mathrm{r}$ & $S 10^{-3}$ & $\begin{array}{c}t \text { CER } \\
(\mathrm{min}) \\
\left(\mathrm{g}_{\text {oil }}\right. \\
\left.\mathrm{g}_{\text {solvent }}{ }^{-1}\right)\end{array}$ & $\begin{array}{c}t_{\mathrm{FER}} \\
(\mathrm{min})\end{array}$ & $\begin{array}{c}\mathrm{kFa} \\
\left(\mathrm{min}^{-1}\right)\end{array}$ & $\begin{array}{c}\mathrm{k}_{\mathrm{sa}} 10^{-3} \\
\left(\mathrm{~min}^{-1}\right)\end{array}$ & $R^{2}$ \\
\hline A & 12.65 & 0.64 & 0.69 & 0.60 & 4.69 & 94.93 & 1.76 & 1.67 & 0.991 \\
B & 12.84 & 0.70 & 0.69 & 1.13 & 2.76 & 50.95 & 0.41 & 1.53 & 0.993 \\
C & 2.04 & 0.50 & 0.69 & 0.60 & 34.90 & 141.08 & 0.08 & 1.01 & 0.986 \\
D & 4.30 & 2.11 & 0.69 & 1.40 & 5.72 & 51.93 & 0.18 & 5.33 & 0.994 \\
E & 12.61 & 1.30 & 0.69 & 0.94 & 2.88 & 68.41 & 0.52 & 3.28 & 0.998 \\
\hline
\end{tabular}

Note. A: $35^{\circ} \mathrm{C} x 14 \mathrm{MPa}, \mathrm{B}: 35^{\circ} \mathrm{C} x 20 \mathrm{MPa}, \mathrm{C}: 55^{\circ} \mathrm{C} x 14 \mathrm{MPa}, \mathrm{D}: 55^{\circ} \mathrm{C} x 20 \mathrm{MPa}, \mathrm{E}: 45$ ${ }^{\circ} \mathrm{C} x 17 \mathrm{MPa}$. Z, dimensionless parameter of Sovová model; $W$, dimensionless parameter of Sovová model; r, easily accessible oil mass; $S$, solubility; $t$ CER, time at which the extraction of the oil from the inside of particles starts; $t_{\mathrm{FER}}$, time at which the extraction of easily accessible solute ends; $\mathrm{k}_{\mathrm{F}}$, solvent-phase mass transfer coefficient; $\mathrm{k}_{\mathrm{s}} \mathrm{a}$, solid-phase mass transfer coefficient; $R^{2}$, coefficient of determination 


\section{Macrothink

The parameter $r(0.69)$ indicates the existence of a high oil level that is easily accessed by the solvent and provided by the milling process. Its value is constant since the raw material was subjected to the same treatment before the extractions. The $Z$ and $W$ coefficients are proportional to the mass transfer parameters in the solvent phase (kFa) and the solid phase $\left(\mathrm{ksa}_{\mathrm{s}}\right)$, respectively. Values were observed in the same order of magnitude for kFa and ksa in the extraction of Candeia oil by using pressurized $\mathrm{CO}_{2}$ (Ribas et al., 2014). As observed, the $\mathrm{k}_{\mathrm{F}} \mathrm{a}$ values exceed the $\mathrm{k}_{\mathrm{s}} \mathrm{a}$ values, and thus demonstrate the higher yield during easy-to-reach oil extraction (Silva et al., 2015).

According to the model, the extraction kinetics are divided into three periods with mass transfer. The first period ( $\left.t_{\text {CER }}\right)$ is fast $(2.76-34.90 \mathrm{~min})$ because it refers to the oil with the most easily accessed to the extraction. In the intermediate period $(t \mathrm{FER})$, the extraction rate decreases due to the exhaustion of the oil that is readily available until the beginning of the third period in which the extraction rate is limited by the internal diffusion mechanism (Santos et al., 2017) with low mass transfer coefficients in the solid phase $\mathrm{k}_{\mathrm{s}} \mathrm{a}\left(1.0110^{-3}\right.$ to $5.3310^{-3} \mathrm{~min}^{-1}$ ) due to the difficulty in extracting the oil contained within the intact cells.

The mathematical modeling indicated a good fit $\left(R^{2}>0.986\right)$ in all experimental conditions investigated. The values reveal that Sovovás model properly represented the $C$. pachystachya oil extraction kinetic behavior in all the cases. The experimental results of extraction kinetics and Sovová's model are shown in Figure 1.

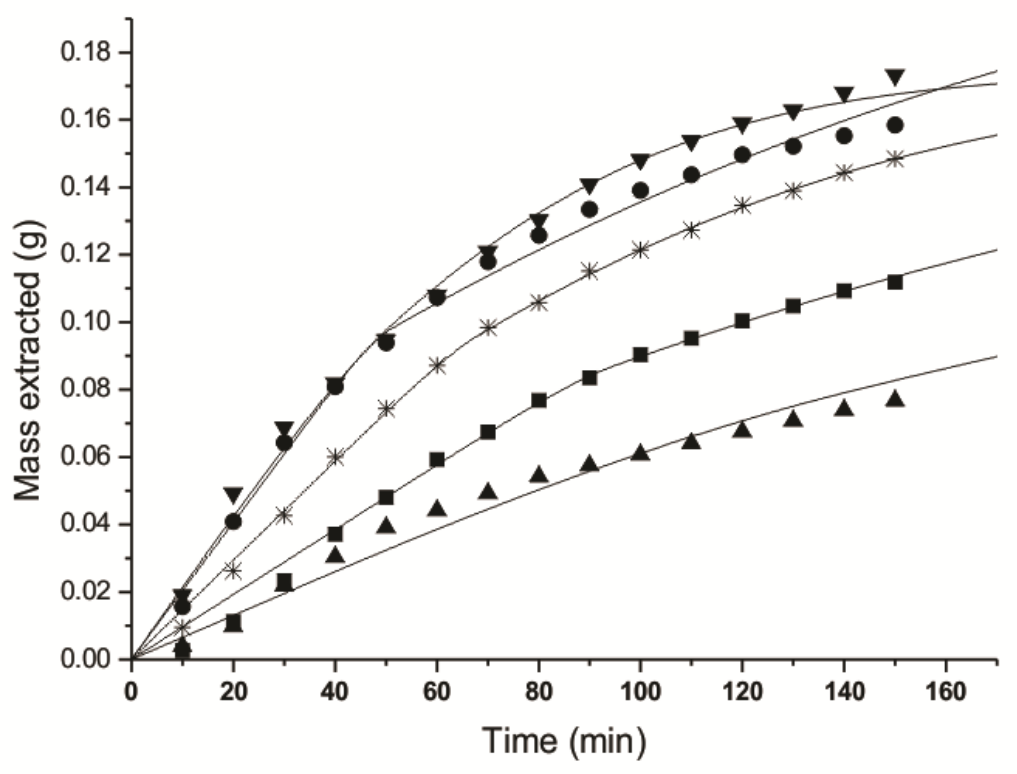

Figure 1. Experimental and modeled kinetic curves for the extraction of C. pachystachya oil by supercritical $\mathrm{CO}_{2}$ extraction using the Sovová model

Note. $\boldsymbol{\nabla}: 55^{\circ} \mathrm{C} x 20 \mathrm{MPa}, \bullet: 35^{\circ} \mathrm{C} \times 20 \mathrm{MPa},{ }^{*}: 45^{\circ} \mathrm{C} x 17 \mathrm{MPa}, \mathbf{\square}: 35^{\circ} \mathrm{C} x 14 \mathrm{MPa}, \boldsymbol{\Delta}: 55$ ${ }^{\circ} \mathrm{C} x 14 \mathrm{MPa}$ 


\section{$\Lambda$ Macrothink}

\subsection{Total Phenolic Content, Antibacterial and Antioxidant Activity}

The low TPC in extracts $\left(61.07-72.37 \mu \mathrm{g}_{\mathrm{GAE}} \mathrm{g}_{\mathrm{oil}}{ }^{-1}\right)$ proves that only a small part of flavonoids was extracted (Table 4). In general, extracts obtained with supercritical $\mathrm{CO}_{2}$ present low extraction of TPC due to the non-polar capacity of this solvent that does not favor the extraction of phenolic compounds, a substance of a generally polar character, and responsible for the antioxidant activity (Dias et al., 2017).

Table 4. TPC, antibacterial activity against $S$. aureus, and antioxidant activity of $C$. pachystachya oils extracted with supercritical $\mathrm{CO}_{2}$

\begin{tabular}{|c|c|c|c|c|c|}
\hline \multirow{2}{*}{$\begin{array}{l}\text { Extracti } \\
\text { on }\end{array}$} & \multirow{2}{*}{$\begin{array}{c}\mathrm{TPC}\left(\mu \mathrm{g}_{\mathrm{GAE}}\right. \\
\left.\mathrm{g}_{\mathrm{oil}}{ }^{-1}\right)\end{array}$} & \multirow{2}{*}{$\begin{array}{l}\text { Antibacterial } \\
\text { activity }^{\mathrm{a}}\end{array}$} & \multicolumn{3}{|c|}{ Antioxidant activity } \\
\hline & & & $\begin{array}{l}\mathrm{IC}_{50}(\mu \mathrm{g} \\
\left.\mathrm{mL}^{-1}\right)\end{array}$ & $\begin{array}{c}\text { FRAP }\left(\mu \text { mol }_{\mathrm{Fe} 2+}\right. \\
\left.\text { goil }^{-1}\right)\end{array}$ & $\begin{array}{c}\text { ABTS }\left(\mu \text { mol }_{\text {Trolox }}\right. \\
\left.\text { goil }^{-1}\right)\end{array}$ \\
\hline A & $64.50 \pm 1.42$ & 7 & $\begin{array}{c}249.85 \pm \\
1.28\end{array}$ & $266.85 \pm 0.01$ & $4177.77 \pm 0.07$ \\
\hline B & $63.10 \pm 1.32$ & 6 & $\begin{array}{c}246.45 \pm \\
1.61\end{array}$ & $266.57 \pm 0.01$ & $3900.00 \pm 0.12$ \\
\hline $\mathrm{C}$ & $72.37 \pm 1.42$ & 9 & $\begin{array}{c}196.39 \pm \\
1.31\end{array}$ & $381.14 \pm 0.02$ & $5288.88 \pm 0.70$ \\
\hline $\mathrm{D}$ & $64.09 \pm 0.73$ & 6 & $\begin{array}{c}234.49 \pm \\
0.62\end{array}$ & $326.14 \pm 0.16$ & $3900.00 \pm 0.15$ \\
\hline $\mathrm{E}$ & $61.07 \pm 0.65$ & 7 & $\begin{array}{c}359.23 \pm \\
0.73\end{array}$ & $191.14 \pm 0.00$ & $3122.22 \pm 0.32$ \\
\hline $\mathrm{NC}$ & - & 0 & 0 & 0 & 0 \\
\hline Amo & - & 15 & - & - & - \\
\hline NS & - & 15 & - & - & - \\
\hline
\end{tabular}

Note. TPC and antioxidant activity values expressed in mean \pm standard deviation $(n=3)$. ${ }^{a}$ Antibacterial activity values expressed in terms of the mean of the inhibition zone $(\mathrm{mm})(n=$ 3). One-way ANOVA post hoc Tukey test A: $35^{\circ} \mathrm{C} x 14 \mathrm{MPa}, \mathrm{B}: 35^{\circ} \mathrm{C} x 20 \mathrm{MPa}, \mathrm{C}: 55^{\circ} \mathrm{C} x$ $14 \mathrm{MPa}$, D: $55^{\circ} \mathrm{C} x 20 \mathrm{MPa}$, E: $45^{\circ} \mathrm{C} x 17 \mathrm{MPa}$, NC: Negative control, Amo: Amoxicillin, NS: Neomycin Sulfate

The oils extracted from $C$. pachystachya leaves were evaluated for their antioxidant capacity. The DPPH method revealed that the temperature and pressure employed in the extraction 
influenced the antioxidant capacity, which ranged from $196.39 \mu \mathrm{g} \mathrm{mL}^{-1}\left(55^{\circ} \mathrm{C} x 14 \mathrm{MPa}\right)$ to $359.23 \mu \mathrm{g} \mathrm{mL}^{-1}\left(45^{\circ} \mathrm{C} \times 17 \mathrm{MPa}\right)$. These results are significant when compared to other studies evaluating the DPPH method from Eremanthus erythropappus supercritical $\mathrm{CO}_{2}$ extract that found $\mathrm{IC}_{50}$ of $716 \mu \mathrm{g} \mathrm{mL}^{-1}$ (Santos et al., 2017), and spent coffee extract who reported $\mathrm{IC}_{50}$ values of 478 to $2369 \mu \mathrm{g} \mathrm{mL}^{-1}$ (Andrade et al., 2012).

In the tests using the FRAP method, the antioxidant potentials of extracts were estimated for their ability to reduce the TPTZ-Fe (III) complex to a TPTZ-Fe (II) complex. The FRAP reducing values were in the range of 191.14-381.14 $\mu \mathrm{mol}_{\mathrm{Fe} 2+} \mathrm{g}_{\mathrm{oil}}{ }^{-1}$. Again, the most effective condition for the recovery of reducing substances in the FRAP assay was observed at $55^{\circ} \mathrm{C}$ and $14 \mathrm{MPa}$. In contrast, reducing capacity of $470 \mu \mathrm{molFe}^{2} \mathrm{~g}_{\mathrm{oil}}{ }^{-1}$ by FRAP method was observed for the supercritical $\mathrm{CO}_{2}$ extract from Populus nigra (Kús et al., 2018). So, it can be showed lower antioxidant activity by FRAP method for the extracted oil.

According to ABTS method, based on the capacity for reducing the chromophore radical $\mathrm{ABTS}^{\circ+}$, the antioxidant potential varies from $3122.22\left(45^{\circ} \mathrm{C} x 17 \mathrm{MPa}\right)$ to $5288.88\left(55^{\circ} \mathrm{C} x\right.$ $14 \mathrm{MPa}) \mu$ molTrolox $\mathrm{g}_{\text {oil }}{ }^{-1}$. These results showed greater antioxidant potential by ABTS method compared to the results reported to candeia wood oil (232.11 to $405.48 \mu$ molTrolox goil $^{-1}$ ) obtained by supercritical $\mathrm{CO}_{2}$ (Santos et al., 2016). The best results for TPC and antioxidant potential were observed for "C" extract obtained at high temperature $\left(55^{\circ} \mathrm{C}\right)$ and low pressure (14 MPa), thus although the temperature does not show statistically significant on the extraction yield, the biological results obtained for " $\mathrm{C}$ " show the significant effect of temperature.

This study involved an evaluation of the in vitro antibacterial activity against $P$. aeruginosa, $E$. coli, and $S$. aureus, but only the last species exhibited inhibition to the concentration used (30 $\mathrm{mg} \mathrm{mL} \mathrm{m}^{-1}$ ). There is no consensus on the acceptable level of inhibition for natural products when compared to antibiotic standards since the material is a mixture of compounds and not a single compound in isolation (Almeida et al., 2014; Waltrich et al., 2015).

A study evaluating the antimicrobial activity of the aqueous and alcoholic extracts of $C$. pachystachya leaves against $S$. aureus showed an inhibition zone of $7 \mathrm{~mm}$ for the alcoholic extract (at $100 \mathrm{mg} \mathrm{mL}^{-1}$ ) (Costa \& Hoscheid, 2018). This inhibitory action was attributed to flavonoids and TPC, since they are well established as antimicrobial agents (Babii et al., 2016; Tsou et al., 2016; Echeverría et al., 2017). However, when compared with this work, we observed the formation of a greater inhibition zone $(9 \mathrm{~mm})$ in a lower concentration $(30 \mathrm{mg}$ $\mathrm{mL}^{-1}$ ) by the same method (agar diffusion method). This fact makes us understand that the main antimicrobial activity found in " $\mathrm{C}$ " extract $\left(55^{\circ} \mathrm{C} x 14 \mathrm{MPa}\right)$ is not due to the unique presence of flavonoids, which showed low content by GC-MS and TPC.

Extant studies have shown discrete effects of $\beta$-sitosterol on S. aureus (Chandra \& Saklani, 2017; Nyawai et al., 2017), and the synergic action of ursolic acid combined with penicillin (Wenyi et al., 2010) and $\beta$-lactams (Catteau et al., 2017) on drug-resistant S. aureus. Hence, the major compound ursolic acid may be acting synergistically with flavonoids and $\beta$-sitosterol to employ the antimicrobial activity observed. 


\section{Conclusion}

The results of the study indicated that the oil extraction of $C$. pachystachya with supercritical $\mathrm{CO}_{2}$ provided satisfactory extract yields in $150 \mathrm{~min}$. The best results were obtained by applying a higher pressure and temperature $\left(20 \mathrm{MPa}\right.$ and $\left.55^{\circ} \mathrm{C}\right)$ investigated in the study with a yield of $1.48 \mathrm{wt} \%$. The examined experimental conditions revealed that only one pressure exhibited a statistically significant effect without extraction yield, however, the biological results obtained show the significant effect of temperature. The oil obtained by applying different conditions did not reveal significant differences concerning its qualitative composition. The major identified compounds were ursolic and pomolic acids. The best results for TPC, antibacterial activity relative to Staphylococcus aureus, and antioxidant potentials were observed on the extract obtained at high temperature $\left(55^{\circ} \mathrm{C}\right)$. For extraction kinetics, the Sovová model provided an adjustment with experimental data.

\section{Acknowledgement}

We thank CNPq for the financial support (Proc. Num. 150785/2017-8).

\section{References}

Almeida, J. R. G. S., Araújo, C. Z., do Ó Pessoa, C., da Costa, M. P., \& Pacheco, A. G. M. (2014). Atividade antioxidante, citotóxica e antimicrobiana de Annona vepretorum Mart. (Annonaceae). Revista Brasileira de Fruticultura, 36, 258-264. https://doi.org/10.1590/S0100-29452014000500030

Andrade, K. S., Gonçalvez, R. T., Maraschin, M., Ribeiro-do-Valle, R. M., Martínez, J., \& Ferreira, S. R. S. (2012). Supercritical fluid extraction from spent coffee grounds and coffee husks: antioxidant activity and effect of operational variables on extract composition. Talanta, 88, 544-552. https://doi.org/10.1016/j.talanta.2011.11.031

Anvisa. Agência Nacional De Vigilância Sanitária. (2010). Farmacopéia Brasileira (5 ed.). Anvisa.

Aragão, D. M. O., Guarize, L., Lanini, J., Da Costa, J. C., Garcia, R. M. G., \& Scio, E. (2010). Hypoglycemic effects of Cecropia pachystachya in normal and alloxan-induced diabetic rats. Journal of Ethnopharmacology, 128, 629-633. https://doi.org/10.1016/j.jep.2010.01.008

Babii, C., Bahrin, L. G., Neagu, A. N., Gostin, I., Mihasan, M., \& Stefan, M. (2016). Antibacterial activity and proposed action mechanism of a new class of synthetic tricyclic flavonoids. J Appl Microbiology, 120(3), 630-637. https://doi.org/10.1111/jam.13048

Brango-Vanegas, J., Costa, G. M., Ortmann, C. F., Schenkel, E. P., Reginatto, F. H., Ramos, F. A., Arévalo-Ferro, C., \& Castellanos, L. (2014). Glycosylflavonoids from Cecropia pachystachya Trécul are quórum sensing inhbitors. Phytomedicine, 21, 670-675. https://doi.org/10.1016/j.phymed.2014.01.001

Catteau, L., Reichmann, N. T., Olson, J., Pinho, M. G., Nizet, V., Bambeke, F. V., \& Quetin-Leclercq, J. (2017). Synergy between Ursolic and Oleanolic Acids from Vitellaria paradoxa Leaf Extract and $\beta$-Lactams against Methicillin-Resistant Staphylococcus aureus: 
In vitro and In vivo activity and Underlying Mechanisms. Molecules, 22(12), 2245. https://doi.org/10.3390/molecules22122245

Chandra, S., \& Saklani, S. (2017). Isolation and Identification of Ficus palmata Leaves and Their Antimicrobial Activities. J Sci Res, 9, 193-200. https://doi.org/10.3329/jsr.v9i2.27806

Choi, C. W., Kim, S. C., Hwang, S. S., Choi, B. K., Ahn, H. J., Lee, M. Y., Park, S. H., \& Kim, S. K. (2002). Antioxidant activity and free radical scavenging capacity between Korean medicinal plants and flavonoids by assay-guided comparison. PlantSci, 163, 1161-1168. https://doi.org/10.1016/S0168-9452(02)00332-1

CLSI, Clinical and Laboratory Standards Institute. (2009). Approved Standard M07-A8: Methods for dilution antimicrobial susceptibility test for bacteria that grow aerobically (8 ed.). CLSI.

Confortin, T. C., Todero, I., Soares, J. F., Brun, T., Luft, L., Ugalde, G. A., Dal Prá, V., Mazutti, M. A., Zabot, G. L., \& Tress, M. V. (2017). Extraction and composition of extracts obtained from Lupinus albescens using supercritical carbon dioxide and compressed liquefied petroleum gas. J Supercrit Fluids, 128, 395-403. https://doi.org/10.1016/j.supflu.2017.06.006

Consolini, A. E., \& Migliori, G. N. (2005). Cardiovascular effects of the South American medicinal plant Cecropia pachystachya (ambay) on rats. Journal of Ethnopharmacology, 96, 417-422. https://doi.org/10.1016/j.jep.2004.09.030

Consolini, A. E., Ragone, M. A., Migliori, G. N., Conforti, P., \& Volonté, M. G. (2006). Cardiotonic and sedative effects of Cecropia pachystachya Mart. (Ambay) on isolated rat hearts and conscious mice. Journal of Ethnopharmacology, 106(1), 90-96. https://doi.org/10.1016/j.jep.2005.12.006

Costa, G. M., Ortmann, C. F., Schenkel, E. P., \& Reginatto, F. H. (2011). An Hplc-Dad method to quantification of main phenolic compounds from leaves of Cecropia species. Journal of Brazilian Chemistry Society, 22(6), 1089-1095. https://doi.org/10.1590/S0103-50532011000600014

Costa, J. C. F., \& Hoscheid, J. (2018). Perfil fitoquímico e avaliação da atividade antimicrobiana de extratos aquoso e etanólico de folhas de Cecropia pachystachya. Fitos, 12(2), 175-185. https://doi.org/10.5935/2446-4775.20180016

Cruz, E. M., Da Silva, E. R., Maquiaveli, C. C., Alves, E. S. S., Lucon Jr, J. F., Dos Reis, M. B. G., De Toledo, C. E. M., Cruz, F. G., \& Vannier-Santos, M. A. (2013). Leishmanicidal activity of Cecropia pachystachya flavonoids: Arginase inhibition and altered mitochondrial $\begin{array}{llll}\text { DNA } & \text { arrangement. } & \text { Phytochemistry, } & \text { 89, }\end{array}$ https://doi.org/10.1016/j.phytochem.2013.01.014

Czaikoski, K., Mesomo, M. C., Krüger, R. L., Queiroga, C. L., \& Corazza, M. L. (2015). Extraction of Campomanesia xanthocarpa fruit using supercritical $\mathrm{CO}_{2}$ and bioactivity assessments. The Journal of Supercritical Fluids, 98, 79-85. https://doi.org/10.1016/j.supflu.2015.01.006 
Da Silva, M. A. B., Melo, L. V. L., Ribeiro, R. V., Souza, J. P. M., Lima, J. C. S., \& Martins, D. T. O. (2010). Ethnobotanical survey of plants used as antihyperlipidemic and anorexigenic by the population of Nova Xavantina-MT, Brazil. Revista Brasileira de Farmacognosia, 20(4), 549-562. https://doi.org/10.1590/S0102-695X2010000400014

Dias, A. L. B., Sergio, C. S. A., Santos, P., Barbero, G. F., Rezende, C. A., \& Martínez, J. (2017). Ultrasound-assisted extraction of bioactive compounds from dedo de moça pepper (L.): Effects on the vegetable matrix and mathematical modeling. J Food Engineering, 198, 26-44. https://doi.org/10.1016/j.jfoodeng.2016.11.020

Echeverría, J., Opazo, J., Mendoza, L., Urzua, A., \& Wilkens, M. (2017). Structure-activity and lipophilicity relationships of selected antibacterial natural flavones and flavanones of chilean flora. Molecules, 22(4), 608. https://doi.org/10.3390/molecules22040608

Farias, K. S., Santos, T. S. N., Paiva, M. R. A. B., Almeida, S. M. L., Guedes, P. T., Vianna, A. C. A., Favaro, S. P., Bueno, N. R., \& Castilho, R. O. (2013). Antioxidant properties of species from the Brazilian cerrado by different assays. Revista Brasileira de Plantas Medicinais, 15(4), 520-528. https://doi.org/10.1590/S1516-05722013000400008

Gazal, M., Ortmann, C. F., Martins, F. A., Streck, E. L., Quevedo, J., De Campos, A. M., Stefanello, F. M., Kaster, M. P., Ghisleni, G., Reginatto, F. H., \& Lencina, C. L. (2014). Antidepressant-like effects of aqueous extract from Cecropia cachystachya leaves in a mouse model of chronic unpredictable stress. Brain Research Bulletin, 108, 10-17. https://doi.org/10.1016/j.brainresbull.2014.07.007

Hatami, T., Moura, L. S., Khamforoush, M., \& Meireles, M. A. A. (2014). Supercritical fluid extraction from Priprioca: Extraction yield and mathematical modeling based on phase equilibria between solid and supercritical phases. $J$ Supercrit Fluids, 85, 62-67. https://doi.org/10.1016/j.supflu.2013.10.012

Hikawczuk, V. J., Saad, J. R., Guardia, T., Juarez, A. O., \& Giordano, O. S. (1998). Anti-inflammatory activity of natural compounds isolated from Cecropia pachystachya. Annals Asociación Química Argentina, 86(3-6), 167-170. https://doi.org/10.1100/tsw.2001.77

Kupski, S. C., Klein, E. J., da Silva, E. A., Palú, F., Guirardello, R., \& Vieira, M. G. A. (2017). Mathematical modeling of supercritical $\mathrm{CO}_{2}$ extraction of hops (Humulus lupulus L.). $J$ Supercrit Fluids, 130, 347-356. https://doi.org/10.1016/j.supflu.2017.06.011

Kús, P., Jerkovic, I., Jakovljevic, M., \& Jokic, S. (2018). Extraction of bioactive phenolics from black poplar (Populus nigra L.) buds by supercritical $\mathrm{CO}_{2}$ and its optimization by response surface methodology. $J$ Pharm Biomed Analysis, 152, 128-136. https://doi.org/10.1016/j.jpba.2018.01.046

Liu, S. H., Mernik, M., Hrcic, D., \& Crepinsek, M. (2013). A parameter control method of evolutionary algorithms using exploration and exploitation measures with a practical application for fitting Sovová's mass transfer model. Applied Soft Computing, 13, 3792-3805. https://doi.org/10.1016/j.asoc.2013.05.010 
Lopes, N. L., Almeida-Couto, J. M. F., Silva, C., Pereira, M. B., Pimentel, T. C., Barão, C. E., \& Cardozo-Filho, L. (2020). Evaluation of the effects of pressurized solvents and extraction process parameters on seed oil extraction in Pachira aquatic. J. Supercrit Fluids, 161, 104823. https://doi.org/10.1016/j.supflu.2020.104823

Maquiaveli, C. C., Da Silva, E. R., Rosa, L. C., Francescato, H. D. C., Lucon Junior, J. F., Silva, C. G. A., Casarini, D. E., Ronchi, F. A., \& Coimbra, T. M. (2014). Cecropia pachystachya extract attenuated the renal lesion in 5/6 nephrectomized rats by reducing inflammation and renal arginase activity. Journal of Ethnopharmacology, 158, 49-57. https://doi.org/10.1016/j.jep.2014.09.042

Martinez-Correa, H. A., Bitencourt, R. G., Kayano, A. C. A. V., Magalhães, P. M., Costa, F. T. M., \& Cabral, F. A. (2017). Integrated extraction process to obtain bioactive extracts of Artemisia annиa L. leaves using supercritical $\mathrm{CO}_{2}$, ethanol and water. Industrial Crops and Products, 95, 535-542. https://doi.org/10.1016/j.indcrop.2016.11.007

Miguel, M. G. (2010). Antioxidant and Anti-Inflammatory Activities of Essential Oils: A Short Review. Molecules, 15, 9252-9287. https://doi.org/10.3390/molecules15129252

Nelder, J. A., \& Mead, R. (1965). A Simplex method for function minimization. Computer Journal, 7, 308-313. https://doi.org/10.1093/comjnl/7.4.308

NIST, National Institute of Standards and Technology Chemistry WebBook. (2015). Thermophysical Properties of Fluid Systems. Available from: http://webbook.nist.gov/chemistry/fluid (accessed 07.04.17).

Nyawai, T. N., Asaruddin, M. R., Rosli, M. F. A., Romli, A. M., Radhakrishnan, S. E., \& Ahmad, M. N. (2017). Pharmacophore Modelling of Phytochemicals from Clinicanthus nutans for Antimicrobial Activity. Transactions on Science and Technology, 4, 498-503. http://tost.unise.org/pdfs/vol4/no4/4x4x498x503.pdf

Ortmann, C. F., Réus, G. Z., Ignácio, Z. M., Abelaira, H. M., Titus, S. E., de Carvalho, P., ... Reginatto, F. H. (2016). Enriched flavonoid fraction from Cecropia pachystachya trécul leaves exerts antidepressant-like behavior and protects brain against oxidative stress in rats subjected to chronic mild stress. Neurotoxicity Research, 29(4), 469-483. https://doi.org/10.1007/s12640-016-9596-6

Ortmann, C. F., Abelaira, H. M., Réus, G. Z., Ignácio, Z. M., Chaves, V. C., Dos Santos, T. C., ... Reginatto, F. H. (2017). LC/QTOF profile and preliminary stability studies of an enriched flavonoid fraction of Cecropia pachystachya Trécul leaves with potential antidepressant-like activity. Biomedical Chromatography, 31(11). https://doi.org/10.1002/bmc.3982

Pacheco, N. R., Pinto, N. D. E., Da Silva, J. M., Mendes, R. D. E., Da Costa, J. D. E., Aragão, D. M., ... Scio, E. (2014). Cecropia pachystachya: a species with expressive in vivo topical anti-inflammatory and in vitro antioxidant effects. BioMed Research International, 2014, 301294. https://doi.org/10.1155/2014/301294 
Pavlic, B., Bera, O., Vidovic, S., Ilic, L., \& Zekovic, Z. (2017). Extraction kinetics and ANN simulation of supercritical fluid extraction of sage herbal dust. $J$ Supercrit Fluids, 130, 327-336. https://doi.org/10.1016/j.supflu.2017.06.015

Ribas, M. C., Mantovani, D., Awadallak, J. A., Canevesi, R. L., Tazinafo, N. M., Cardozo-Filho, L., ... Silva, E. A. (2014). Study of candeia oil extraction using pressurized fluids and purification by adsorption process. $J$ Supercrit Fluids, 92, 177-182. https://doi.org/10.1016/j.supflu.2014.04.009

Rivera-Mondragón, A., Ortíz, O. O., Bijttebier, S., Vlietinck, A., Apers, S., Pieters, L., \& Caballero-George, C. (2017). Selection of chemical markers for the quality control of medicinal plants of the genus Cecropia. Pharm. Biology, 55, 1500-1512. https://doi.org/10.1080/13880209.2017.1307421

Rocha, F. F., Lima-Landman, M. T., Tanae, M. M., De Lima, T. C., \& Lapa, A. J. (2007). Antidepressant-like effect of Cecropia glazioui sneth and its constituents - In Vivo and in vitro characterization of the underlying mechanism. Phytomedicine, 14(6), 396-402. https://doi.org/10.1016/j.phymed.2007.03.011

Rodrigues, V. E. G., \& Carvalho, D. A. (2001). Levantamento etnobotânico de plantas medicinais no domínio do Cerrado na região do Alto Rio Grande - Minas Gerais. Ciência e Agrotecnologia, 25(1), 102-123. https://doi.org/10.1590/S1516-05722013000400009

Santos, K. A., Bariccatti, R. A., Cardozo-Filho, L., Schneider, R., Palú, F., Silva, C., \& Silva, E. A. (2015). Extraction of crambe seed oil using subcritical propane: Kinetics, characterization and modeling $J$ Supercrit Fluids, 104, 54-61. https://doi.org/10.1016/j.supflu.2015.05.026

Santos, K. A., Klein, E. J., Gazim, Z. C., Gonçalves, J. E., Cardozo-Filho, L., Corazza, M. L., \& Silva, E. A. (2016). Wood and industrial residue of candeia (Eremanthus erythrop appus): supercritical $\mathrm{CO}_{2}$ oil extraction, composition, antioxidant activity and mathematical modeling. J Supercrit Fluids, 114, 1-8. https://doi.org/10.1016/J.SUPFLU.2016.02.015

Santos, K. A., Frohlich, P. C., Hoscheid, J., Tiuman, T. S., Gonçalves, J. E., Cardozo-Filho, L., \& Silva, E. A. (2017). Candeia (Eremanthus erythroppapus) oil extraction using supercritical $\mathrm{CO}_{2}$ with ethanol and ethyl acetate cosolvents. J Supercrit Fluids, 128, 323-330. https://doi.org/10.1016/j.supflu.2017.03.029

Shanmugam, S., Rajendran, K., \& Suresh, K. (2012). Traditional uses of medicinal plants among the rural people in Sivagangai district of Tamil Nadu Southern India. Asian Pacific J Trop Biomed, S429-S434. https://doi.org/10.1016/S2221-1691(12)60201-9

Silva, C. M., Zanqui, A. B., Gohara, A. K., Souza, A. H. P., Cardozo-Filho, L., Visentainer, J. V., ... Matsushita, M. (2015). Compressed n-propane extraction of lipids and bioactive compounds from Perilla. $J$ Supercrit Fluids, $102, \quad$ 1-8. https://doi.org/10.1016/j.supflu.2015.03.016 
Singleton, V. L., \& Rossi, J. A. (1965). Colorimetry of total phenolics with phosphomolybdic-phosphotungstic acid reagents. American Journal Enolology and Viticulture, 20(2), 144-158. https://www.ajevonline.org/content/16/3/144

Souza, C. D., \& Felfili, J. M. (2006). Uso de plantas medicinais na região de Alto Paraíso de Goiás, GO, Brasil. Acta Botanica Brasilica, 20(1), 135-142. https://doi.org/10.1590/S0102-33062006000100013

Souza, D. O., Tintino, S. R., Figueredo, F. G., Borges, M. C. M., Braga, M. F. B. M., Felipe, C. F. B., ... Kerntopf, M. R. (2014). Atividade antimicrobiana e moduladora de Cecropia pachystachya Trécul sobre a ação de aminoglicosídeos. Revista Cubana de Plantas Medicinales, 19(1), 121-132. Disponível em: http://scielo.sld.cu/scielo.php?script=sci_abstract\&pid=S1028-47962014000300001\&lng=es $\& n r m=i s o \& t \operatorname{lng}=p t$

Souza-Moreira, T. M., Salgado, H. R. N., \& Pietro, R. C. L. R. (2010). O Brasil no contexto de controle de qualidade de plantas medicinais. Revista Brasileira de Farmacognosia 20(3), 435-440. https://doi.org/10.1590/S0102-695X2010000300023

StatSoft (2007) Inc Statistica: data analysis software system, version 8.0

Subroto, E., Widjojokusumo, E., Veriansyah, B., \& Tjandrawinata, R. R. (2017). Supercritical $\mathrm{CO} 2$ extraction of candlenut oil: process optimization using Taguchi orthogonal array and physicochemical properties of the oil. J Food Sci Technol, 54, 1286-1292. https://doi.org/10.1007/s13197-017-2542-7

Tsou, L. K., Lara-Tejero, M., RoseFigura, J., Zhang, Z. J., Wang, Y. C., Yount, J. S., ... Hang, H. C. (2016). Antibacterial flavonoids from medicinal plants covalently inactivate type III protein secretion substrates. J Am Chem Soc, 138(7), 2209-2218. https://doi.org/10.1021/jacs.5b11575

USP. (2011). United States Pharmacopeia (34 ed.). NF 29. The United States Pharmacopeial Convention.

Velázquez, E., Tournier, H. A., Buschiazzo, P. M., Daavedra, G., \& Schinella, G. R. (2003). Antioxidant activity of Paraguayan plant extract. Fitoterapia, 74(1-2), 91-97. https://doi.org/10.1016/S0367-326X(02)00293-9

Waltrich, K. K., Hoscheid, J., \& Prochnau, I. S. (2015). Antimicrobial activity of crude extracts and fractions of Vernonia polyanthes Less (assa-peixe) flowers. Rev Bras Pl Med, 17(4), 909-914. https://doi.org/10.1590/1983-084X/14_110

Wenyi, K., Yanli, S., Zhigiang, J., \& Jinmei, W. (2010). Aplication of natural compound ursolic acid on antibiosis. Chima Patent, CN 101543499

Yang, Y. P., Tasneem, S., Daniyal, M., Zhang, L., Jia, Y. Z, Jian, Y. Q, .. Wang, W. (2020). Lanostane tetracyclic triterpenoids as important sources for anti-inflammatory drug discovery. WJTCM, 6(3), 229-238. https://doi.org/10.4103/wjtcm.wjtcm_17_20 


\section{Appendix}

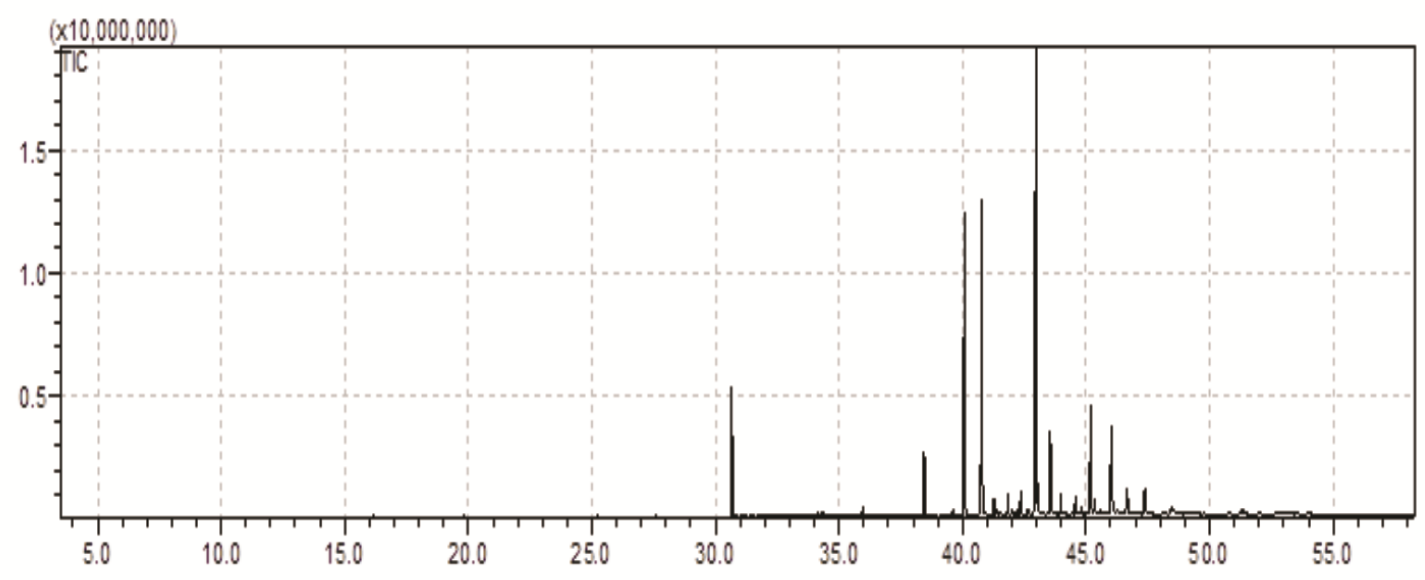

Appendix. Screening by GC-MS of Cecropia pachystachya oil

\section{Copyright Disclaimer}

Copyright for this article is retained by the author(s), with first publication rights granted to the journal.

This is an open-access article distributed under the terms and conditions of the Creative Commons Attribution license (http://creativecommons.org/licenses/by/4.0/). 